\title{
ARTIKELEN
}

\section{Realisatie van maatschappelijke initiatieven}

\author{
Een overzicht van in te zetten instrumenten*
}

\section{J.W.M. Mentink}

\section{Inleiding}

Nederland staat voor grote maatschappelijke opgaven, denk alleen al aan de vraagstukken rond klimaatadaptatie, energietransitie en stikstof. Maatschappelijke partijen laten zien dat zij samen willen werken aan die opgaven, bijvoorbeeld bedrijven die samen willen werken aan een schone branche met een goed imago of juist samen sociaal en maatschappelijk verantwoord willen ondernemen, maar ook buurtinitiatieven voor speeltuinen of bibliotheken. Nieuw is het niet dat maatschappelijke partijen willen bijdragen aan publieke belangen. Nederland is van oudsher een land waar maatschappelijke partijen zich mengen in het maatschappelijk debat en een positie innemen van waaruit zij informeel of formeel invloed kunnen en mogen uitoefenen op overheidsbeleid. Tegelijkertijd zoeken die maatschappelijke partijen naar manieren om hun initiatieven te realiseren.

Aan de overheid staan verschillende reguleringsinstrumenten ter beschikking om initiatieven van maatschappelijke partijen te ondersteunen. De (in)formele rol die overheid en maatschappelijke partijen hebben bij de inzet van die instrumenten is voor elk instrument anders. Gevolg daarvan is dat ook de mogelijkheden om bepaalde (eigen) doelen te realiseren voor overheid en maatschappelijke partijen per instrument verschillend zijn. Dat maakt de keuze voor het juiste instrument essentieel. In deze bijdrage wordt een aantal van deze instrumenten besproken. Daaronder is, gelet op het onderwerp van dit themanummer, vanzelfsprekend ook het instrument algemeenverbindendverklaring. Dit instrument wordt geplaatst naast en vergeleken met andere instrumenten die de overheid kan inzetten om maatschappelijke initiatieven te ondersteunen. In een indeling van privaat naar publiek worden de volgende instrumenten besproken: zelfregulering, publiek-private afspraken, algemeenverbindendverklaring, verordeningen van de bedrijfslichamen, het wetsvoorstel ruimte voor duurzaamheidsinitiatieven en reguliere wetgeving. Er wordt aandacht geschonken aan de mate waarin de verschillende instrumenten geschikt zijn om maatschappelijke initiatieven te realiseren, de rollen die publieke en private partijen hebben bij de inzet van de instrumenten, en de mogelijkheden en beperkingen van deze instrumenten.

* De auteur schrijft dit artikel op persoonlijke titel. 


\section{Zelfregulering}

Veel maatschappelijke initiatieven komen tot stand in het kader van zelfregulering. ${ }^{1}$ Bij zelfregulering gaat het om regulering die door private partijen zelfstandig en op eigen initiatief wordt ontplooid. Dit betreft het terrein waar private partijen zelfstandig handelen en waar de overheid in beginsel geen rol heeft. ${ }^{2}$ Dit brengt met zich dat het toepassingsbereik van deze activiteiten bepaald wordt door de partijen die deze activiteiten ontplooien. Overigens kan het hier gaan om een breed scala aan partijen, van non-gouvernementele organisaties (ngo) tot belangenvertegenwoordigers van een sector of beroepsgroep. Ook kan de zelfregulering die door private partijen ontplooid wordt veel verschillende vormen aannemen.

Kenmerk van zelfregulering is dat partijen zelf verantwoordelijkheid nemen en voorschriften opstellen, ofwel om gezamenlijk te voldoen aan wettelijke regels, ofwel om al dan niet aanvullend op wettelijke regels gezamenlijk aan hogere standaarden te voldoen. Een voorbeeld zijn de verschillende kwaliteitssystemen in de veehouderij waarmee verschillende partijen samen beogen te borgen dat Nederlandse landbouwproducten voldoen aan een hoog kwaliteitsniveau en ten behoeve waarvan ook bovenwettelijke eisen worden gesteld. Een ander bekend voorbeeld betreft de Nederlandse Reclame Code. Een set regels over reclameuitingen die door partijen uit de betreffende sector is opgesteld. Deze code kent bovendien een regime voor klachten, waardoor naleving van de code wordt bevorderd.

De mate waarin dergelijke vormen van zelfregulering kans van slagen hebben, is afhankelijk van de mate waarin de verschillende partijen in het veld zich aan het systeem van zelfregulering willen verbinden. Hoe meer partijen zich aan een dergelijk systeem willen binden, hoe groter de kans dat daadwerkelijk resultaten kunnen worden behaald en hoe groter de potentiële impact van de zelfregulering. Echter, zelfregulering kent ook belangrijke beperkingen. Zo leidt zelfregulering tot hogere eisen en is een systeem nodig waarin die eisen worden gecontroleerd. Dit leidt in de regel tot hogere kosten. En het is de vraag of die kosten kunnen worden terugverdiend. Een consument moet bijvoorbeeld bereid zijn te betalen voor een product dat als gevolg van zelfregulering voldoet aan hogere eisen en daardoor een hogere kostprijs heeft. De praktijk heeft uitgewezen dat die bereidheid niet altijd bestaat of slechts beperkt aanwezig is. ${ }^{3}$ En zo mogelijk nog belangrijker is dat partijen in staat moeten zijn om een voldoende mate van orga-

1 Zie over zelfregulering in algemene zin F.J. van Ommeren, 'Zelfregulering in algemene zin', in: S.E. Zijlstra (red.), Wetgeven. Handboek voor de centrale en decentrale overheid, Deventer: Kluwer 2012, p. 210 e.v.

2 Dit geldt tenminste voor de vrije of zuivere zelfregulering. Daarnaast worden ook onderscheiden vervangende zelfregulering en wettelijk geconditioneerde of wettelijk gestructureerde zelfregulering. Van Ommeren 2012, p. 213.

3 Zie bijv. de analyse van de ACM over de duurzaamheidsafspraken over de Kip van Morgen (www.acm.nl/nl/publicaties/publicatie/13758/Analyse-ACM-van-duurzaamheidsafspraken-Kipvan-Morgen). 
nisatie te bereiken om zelfregulering op te pakken en tot uitvoering te brengen. De zogenoemde free-riderproblematiek is hier een veelgehoord bezwaar. ${ }^{4}$ Niet zelden klinkt dan ook een roep om ondersteuning van zelfregulering door de overheid.

Indien de overheid wordt verzocht zelfregulering te ondersteunen, dan komt aanwijzing 2.5 van de Aanwijzingen voor de regelgeving in beeld. Uit deze aanwijzing volgt dat bij het bepalen van de keuze voor een mogelijkheid tot overheidsinterventie om een doel te bereiken zo veel mogelijk wordt aangesloten bij het zelfregulerend vermogen in de maatschappij. Dit, blijkens de toelichting bij deze aanwijzing, omdat uit de eisen van met name efficiëntie en evenredigheid voortvloeit dat voor direct overheidsingrijpen slechts plaats is indien van het zelfregulerend vermogen van de maatschappij - ook versterkt met ondersteunende overheidsmaatregelen - niet voldoende resultaten te verwachten zijn. Indien ondersteuning van zelfregulering door de overheid inderdaad nodig is, moet daarbij zo veel mogelijk worden aangesloten bij die zelfregulering. Voor die ondersteuning geldt, wederom vanuit de eisen van efficiëntie en evenredigheid, dat de lichtst mogelijke vorm van ondersteuning moet worden gekozen.

De wijzen waarop ondersteuning van zelfregulering plaats kan hebben, zijn divers. Ik noem enkele voorbeelden. Een bewindspersoon kan expliciet de steun voor een bepaalde vorm van zelfregulering uitspreken. Ook kan de overheid door voorlichting zelfregulering onder de aandacht brengen. Zelfregulering kan verder worden ondersteund door een financiële bijdrage aan de organisatie daarachter te leveren. Daarnaast is het voor de overheid ook mogelijk om zelfregulering onderdeel te maken van het eigen toezichtsbeleid. ${ }^{5}$ Dat kan bijvoorbeeld door het toezicht aan te passen voor deelnemers aan een systeem van zelfregulering dat aan bepaalde standaarden voldoet. Deze vorm van ondersteuning lijkt vooral voor de overheid voordelen te hebben, omdat het toezicht op de eigen normen efficiënter kan worden ingericht. Tegelijkertijd wordt, juist vanwege dit aangepaste toezicht, de deelname aan een dergelijk systeem aantrekkelijker.

Indien geen van deze vormen van ondersteuning voldoende blijkt, kan ook gedacht worden aan het inzetten van het wetgevingsinstrumentarium ter ondersteuning van zelfregulering. Dat kan bijvoorbeeld door het inzetten van vervangende zelfregulering, waarbij de mogelijkheid om wetgeving in te zetten wordt gebruikt om zelfregulering af te dwingen. Een voorbeeld hiervan is de Telecommunicatiewet, waarin een grondslag wordt opgenomen om het overstappen tussen telecomproviders te vergemakkelijken. Deze grondslag is bedoeld om te gebruiken indien de sector zelf niet via zelfregulering tot dergelijke afspraken komt. ${ }^{6}$ Daarnaast kan ook wettelijk geconditioneerde zelfregulering worden ingezet. Hierbij wordt zelfregulering van een wettelijk kader voorzien. Wettelijk

4 Zie voor een opsomming van voor- en nadelen van zelfregulering Van Ommeren 2012, p. 212.

5 Zie hiervoor het kabinetsstandpunt 'Certificatie en accreditatie in het kader van het overheidsbeleid' (Kamerstukken II 2015/16, 29304, nr. 6).

6 Kamerstukken II 2019/20, 35368, nr. 2, p. 10. 
geconditioneerde zelfregulering kan veel verschillende vormen aannemen. Denk bijvoorbeeld aan het wettelijk verankeren van certificatie of normalisatie of het in regelgeving verbinden van gevolgen aan het (niet-)naleven van private standaarden. Een veel verdergaande vorm is om in wetgeving een verplichting tot (deelname aan) zelfregulering op te nemen. ${ }^{7}$

Ondersteuning van zelfregulering is dus op vele manieren mogelijk. Hoe zwaarder de vorm van ondersteuning en hoe intensiever de rol die de overheid daarbij heeft, hoe meer de vraag zich opdringt of zelfregulering, ondersteund door de overheid, nog wel het juiste instrument is, juist ook vanwege de eerdergenoemde eisen van efficiëntie en evenredigheid, die zowel gelden voor de inzet van overheidsinterventie als voor de wijze waarop deze plaatsheeft.

\section{Publiek-private afspraken}

Vaak wordt publiek-private samenwerking vormgegeven door het maken van afspraken. Als de rijksoverheid bij zulke afspraken is betrokken, worden zij (veelal) gegoten in de vorm van een convenant: een schriftelijke en door partijen ondertekende afspraak of een samenstel van zulke afspraken, hoe ook genoemd, van de centrale overheid, met een of meer wederpartijen, die betrekking of mede betrekking heeft op de uitoefening van publiekrechtelijke bevoegdheden of anderszins gericht of mede gericht is op het voorbereiden dan wel realiseren van rijksoverheidsbeleid (aanwijzing 1, tweede lid, van de Aanwijzingen voor convenanten). Er is hier een rol voor zowel private partijen als de overheid, waarbij partijen op basis van een gelijkwaardige positie afspraken maken. De partijen bij het convenant bepalen immers samen de inhoud van de te maken afspraken. Deelnemers aan een convenant zijn divers. Waar het private partijen betreft kan het bijvoorbeeld gaan om ngo's of vertegenwoordigers van een sector of beroepsgroep. Deze laatste groep kan zelfstandig of namens de bij hem aangesloten ondernemingen handelen. Waar de rijksoverheid partij is bij een convenant moeten de Aanwijzingen voor convenanten worden toegepast. Deze aanwijzingen bevatten voorschriften over de afwegingen die aan bod moeten komen bij het aangaan van convenanten, de inhoudelijke eisen aan convenanten en de procedurele eisen voor convenanten. ${ }^{8}$

Een convenant is voor de overheid een instrument om maatschappelijke initiatieven op basis van een gelijkwaardige verhouding te ondersteunen. Een voorbeeld is de Green Deal-aanpak, waarmee samenwerking om een duurzame en groene eco-

7 Zie bijv. art. 8.10 van de Regeling diergeneesmiddelen, waarin partners uit de veehouderijsectoren verplicht worden om zelf kwaliteitscontrole, gericht op de naleving van bepaalde wettelijke voorschriften, uit te voeren. Daarbij wordt wel opgemerkt dat deze verplichting voortvloeit uit Europese regelgeving.

8 Zie over convenanten F.J. van Ommeren, 'Convenanten', in: S.E. Zijlstra (red.), Wetgeven. Handboek voor de centrale en decentrale overheid, Deventer: Kluwer 2012, p. 207-208. 
nomie te realiseren wordt gefaciliteerd. ${ }^{9}$ Door overheden, waaronder de rijksoverheid, bedrijven en andere organisaties, zoals ngo's en sectorvertegenwoordigers, worden afspraken gemaakt om duurzame initiatieven mogelijk te maken, waarbij iedere partij haar eigen verantwoordelijkheid heeft. Inzet vanuit de overheid bij de te sluiten Green Deals is vaak om partijen samen te brengen en waar nodig ruimte (bijvoorbeeld in regels) te creëren, zodat partijen nieuwe duurzame initiatieven kunnen realiseren. Er zijn sinds de start van de Green Deal-aanpak in 2011 inmiddels ruim tweehonderd Green Deals getekend, onder andere op de terreinen klimaat, energie, biodiversiteit en voedsel.

Een ander voorbeeld van sturing door middel van publiek-private afspraken zijn de internationaal maatschappelijk verantwoord ondernemen-convenanten (hierna: IMVO-convenanten). In deze convenanten, die voor verschillende bedrijfssectoren met hoge MVO-risico's worden gesloten, worden afspraken gemaakt over internationaal maatschappelijk verantwoord ondernemen. Dit vanuit de wens dat bedrijven die in Nederland actief zijn, maar ook internationaal opereren, dit op een maatschappelijk verantwoorde manier doen. Het doel van deze convenantenaanpak is tweeledig. Ten eerste om de situatie, bijvoorbeeld ten aanzien van kinderarbeid, lage lonen en milieu, in een aantal risicogebieden te verbeteren. En ten tweede om als deelnemende partijen samen te zoeken naar oplossingen voor problemen die bedrijven zelfstandig niet kunnen oplossen. Inzet van de overheid is om deze aanpak waar mogelijk te ondersteunen.

Convenanten bieden voor private partijen en de overheid een manier om te sturen op gezamenlijke doelen en hierover afspraken te maken. Een voordeel van deze aanpak is dat de gezamenlijke verantwoordelijkheid en inzet van zowel de overheid als private partijen tot uitdrukking komen door de gezamenlijke ondertekening. Beperking van dit instrument is evenwel dat alleen de aangesloten partijen gebonden zijn aan de afspraken die in het convenant zijn opgenomen. Het convenant is dus niet per definitie een instrument om een hele sector te binden. Sommige convenanten worden ondertekend door partijen die een bepaalde sector of branche vertegenwoordigen. Naleving van de gemaakte afspraken kan dan niet zonder meer worden afgedwongen bij alle bedrijven die in die sector of branche actief zijn. Ook is de afdwingbaarheid van convenanten niet altijd eenvoudig omdat onvoldoende concrete afspraken worden gemaakt, of onvoldoende duidelijk is wie welke verplichting op zich neemt. Bovendien moet er altijd aandacht zijn voor de mededingingsrechtelijke toets. De te maken afspraken mogen geen strijd opleveren met het kartelverbod, ook niet als de overheid bij die afspraken partij is. ${ }^{10}$ Wel kan de positieve werking van een convenant ertoe leiden dat meer partijen toetreden en een convenant een bredere werking krijgt.

9 Zie over de achtergrond van de Green Deal-aanpak Kamerstukken II 2011/12, 33043, nr. 1, p. 1-4 en www.greendeals.nl. Dit betreft de Nederlandse Green Deal-aanpak, niet te verwarren met de Europese (klimaat-)Green Deal.

10 Zie ook G.J. van Midden, 'Het mededingingsrechtelijke speelveld bij bestuursakkoorden', RegelMaat 2019, afl. 2, p. 126-128. 


\section{Algemeenverbindendverklaring}

Algemeenverbindendverklaring is een instrument waarbij de overheid op verzoek van een partij, onder bepaalde voorwaarden, de gelding van private afspraken kan verbreden tot deelnemers die geen partij zijn bij die afspraak. De bevoegdheid tot algemeenverbindendverklaring bestaat alleen als daar een wettelijke grondslag voor is gecreëerd. Het proces van algemeenverbindendverklaring vangt aan met een afspraak die door private partijen is gemaakt en die door deze partijen aan de betreffende bewindspersoon wordt voorgelegd met het verzoek de afspraak algemeen verbindend te verklaren. De bewindspersoon toetst vervolgens of aan de voorwaarden voor algemeenverbindendverklaring wordt voldaan. Daaronder is in de regel het meerderheidsvereiste: een meerderheid van de subjecten die onder de reikwijdte van de afspraken vallen, moet instemmen met de verbindendverklaring daarvan. ${ }^{11}$ Indien de bewindspersoon besluit om over te gaan tot algemeenverbindendverklaring wordt eenieder die onder de werkingssfeer van de afspraken valt aan die afspraken gebonden.

Het terrein waarop het instrument algemeenverbindendverklaring sinds lange tijd wordt ingezet, en waar dus ruime ervaring met de toepassing van dit instrument is opgedaan, is dat van de cao's. Door dit instrument worden sociale partners ondersteund bij het realiseren van goede afspraken over arbeidsvoorwaarden en arbeidsomstandigheden. Tegelijkertijd wordt voorkomen dat het voor partijen mogelijk is om zich aan deze afspraken te onttrekken en ten nadele van de werkgever of werknemer te concurreren op arbeidsvoorwaarden of arbeidsomstandigheden. ${ }^{12}$ Dit voorbeeld laat goed zien voor welke situatie het instrument algemeenverbindendverklaring kan worden ingezet. Het gaat om die gevallen waarin het enerzijds wenselijk is om zelfregulering te ondersteunen door alle partijen aan de te maken afspraak te binden, maar anderzijds geen sprake is van een dusdanig zwaar publiek belang dat de overheid de materie zelf zou moeten regelen. Daar komt bij dat partijen zelf in staat moeten zijn om de naleving van de afspraken af te dwingen. Er blijft immers sprake van private afspraken. De georganiseerde partijen zullen naleving van die afspraken zelf, met gebruikmaking van het privaatrechtelijk instrumentarium, moeten afdwingen. ${ }^{13}$

Ook in het Europees recht is de algemeenverbindendverklaring een bekend instrument. Zo biedt de Europese Gemeenschappelijke Marktordeningsverordening (hierna: GMO) ${ }^{14}$ lidstaten de mogelijkheid om producentenorganisaties,

11 M.J. Dresden, Algemeenverbindendverklaring van overeenkomsten in het milieubeleid, Den Haag: Sdu Uitgevers 2004, p. 207-208.

12 Kamerstukken II 2008/09, 29544, nr. 177, p. 1.

13 Dresden maakt overigens wel melding van de mogelijkheid tot bestuursrechtelijke en zelfs strafrechtelijke handhaving van algemeen verbindend verklaarde overeenkomsten, maar pleit zelf voor civielrechtelijke handhaving. Dresden 2004, p. 232.

14 Verordening (EU) 1308/2013 van het Europees Parlement en de Raad van 17 december 2013 tot vaststelling van de gemeenschappelijke ordening van landbouwproducten en tot intrekking van verordeningen (EEG) 922/72, (EEG) 234/79, (EG) 1037/2001 en (EG) 1234/2007 (PbEU 2013, L 347). 
unies van producentenorganisaties en brancheorganisaties in de land- en tuinbouwsector te erkennen. De GMO maakt het voorts mogelijk om voorschriften van, of financiële bijdragen aan, erkende organisaties onder bepaalde voorwaarden verbindend te verklaren voor niet bij die erkende organisaties aangesloten marktdeelnemers. In Nederland is ter uitvoering van deze mogelijkheid de Regeling producenten- en brancheorganisaties vastgesteld. In aanvulling daarop meldde de minister van Landbouw, Natuur en Voedselkwaliteit aan de Tweede Kamer de ruimte voor bredere toepassing van het instrument algemeenverbindendverklaring in de land- en tuinbouwsector verder te onderzoeken. ${ }^{15}$ Dit ter uitvoering van het regeerakkoord 2017 'Vertrouwen in de toekomst', ${ }^{16}$ waarin hierover het volgende staat:

'Op verzoek van branche- of producentenorganisaties kan de overheid sectorale afspraken in de land- en tuinbouw algemeen verbindend verklaren (AVVen), bijvoorbeeld voor de financiering van onderzoek naar innovatieve producten en het verplichten van duurzamere standaarden. Hierbij wordt rekening gehouden met Europese kaders en de Nederlandse exportpositie.'

De vraag dringt zich op hoe een brede toepassing van dit instrument zich verhoudt tot het publiek belang en normstelling door de overheid. Juist omdat er, zoals eerder toegelicht, voor de overheid geen mogelijkheid is om inhoudelijk te sturen op de te maken afspraken of een rol in te nemen om de naleving van de afspraken daadwerkelijk af te dwingen. Om die redenen heeft de minister aan de Afdeling advisering van de Raad van State voorlichting gevraagd over de gevallen waarin algemeenverbindendverklaring een alternatief kan zijn voor normstelling door de overheid. Op het moment van afronden van deze bijdrage is deze voorlichting nog niet beschikbaar. Het blijft dus nog afwachten of en hoe de inzet van algemeenverbindendverklaring op het landbouwterrein kan en zal worden verruimd.

Met de toepassing van de algemeenverbindendverklaring kan de overheid een maatschappelijk initiatief van een of meerdere private partijen ondersteunen. De overheid heeft bij toepassing van dit instrument een andere rol dan de verzoekende partijen. De afspraken worden gemaakt door private partijen. De overheid heeft hierbij geen rol en heeft dus geen invloed op de inhoud van die afspraken. De rol van de overheid is beperkt tot het creëren van een bevoegdheid om afspraken algemeen verbindend te verklaren en het in dat verband vaststellen van de voorwaarden waaronder dit mogelijk is, en daarnaast het nemen van het besluit om voorgelegde afspraken al dan niet algemeen verbindend te verklaren. Dat maakt ook dat de mogelijkheden om door middel van dit instrument te sturen op bepaalde doelen en de beweegredenen om dit instrument in te zetten anders zijn voor private partijen dan voor de overheid. Private partijen kunnen afspraken

16 Zie www.rijksoverheid.nl/regering/documenten/publicaties/2017/10/10/regeerakkoord-2017vertrouwen-in-de-toekomst. 
maken om bepaalde doelen te realiseren en verzoeken deze afspraken algemeen verbindend te verklaren, om zo de hele sector te binden aan deze afspraken. Een belangrijke beperking ligt evenwel in het mededingingsrecht. Ook afspraken die met het oog op een verzoek tot algemeenverbindendverklaring worden gemaakt, mogen niet in strijd zijn met het kartelverbod. ${ }^{17}$ Een andere belangrijke beperking is gelegen in de uitvoerbaarheid en de afdwingbaarheid van algemeen verbindend verklaarde afspraken. Private partijen moeten de algemeen verbindend verklaarde afspraken zelf uitvoeren en de naleving daarvan zelf, met behulp van het privaatrecht, afdwingen. In de praktijk blijkt dit problematisch voor de toepassing van dit instrument. ${ }^{18}$ Aan de andere kant kan algemeenverbindendverklaring voor private partijen dienen om de te maken afspraken te legitimeren. Een besluit tot algemeenverbindendverklaring geeft tenslotte aan dat de overheid de gemaakte afspraken onderschrijft en het belangrijk vindt dat eenieder daaraan wordt gebonden. Met dit instrument is het voor de overheid mogelijk om met beperkte inzet van capaciteit en middelen een maatschappelijk initiatief te ondersteunen.

\section{Verordeningen van de bedrijfslichamen}

In het verleden werd in de sectoren waar product- en bedrijfschappen actief waren de verordenende bevoegdheid van die bedrijfslichamen veelvuldig gebruikt om te sturen op sectorale doelstellingen. Met de opheffing van de product- en bedrijfschappen met ingang van 1 januari 2015 is deze mogelijkheid komen te vervallen. Om het 'gat' dat hiermee is ontstaan op te vullen, zoeken partijen naar alternatieve instrumenten om hun doelen te realiseren. Een gelijkwaardig alternatief voor het vervallen instrument is, vanwege de specifieke kenmerken van werking van de verordeningen van de bedrijfslichamen, niet voorhanden. Tegelijkertijd biedt artikel 134 van de Grondwet nog steeds een grondslag voor de instelling van openbare lichamen voor beroep en bedrijf. Herinvoering van de product- en bedrijfschappen behoort daarmee (in ieder geval theoretisch bezien) tot de mogelijkheden. Vanwege het veelvuldig gebruik van dit instrument in het verleden en de behoefte die daaraan bij private partijen nog steeds lijkt te bestaan, wordt het instrumentarium van de product- en bedrijfschappen hier ook besproken.

Aan de oprichting van de bedrijfslichamen in de jaren vijftig lagen drie politiekideologische gedachten ten grondslag: het subsidiariteitsbeginsel, het beginsel van soevereiniteit in eigen kring en het beginsel van functionele decentralisatie. ${ }^{19}$ Op grond van de toenmalige Wet op de bedrijfsorganisatie (Wet BO) konden product- en bedrijfschappen worden ingesteld. De productschappen waren bedoeld

17 Zie ook Van Midden 2019, p. 126-128.

18 Dit geldt te meer in sectoren waar veel (kleine) bedrijven actief zijn. Deze bedrijven zijn vaak niet volledig in beeld van de partijen die de naleving van de algemeen verbindend verklaarde afspraken moeten controleren en afdwingen. Ook de rechtsgang om naleving af te dwingen blijkt in de praktijk, zeker in sectoren met veel deelnemers, een barrière. Zie voor een voorbeeld van deze problematiek Kamerstukken II 2016/17, 33910, nr. 26, p. 3. 
voor ondernemingen die in het bedrijfsleven verschillende functies vervulden ten aanzien van bepaalde (groepen van) producten (verticaal), terwijl de bedrijfschappen bedoeld waren voor ondernemingen die gelijke of verwante functies vervulden (horizontaal). ${ }^{20}$ De product- en bedrijfschappen hadden tot taak om een het algemeen belang dienende bedrijfsuitoefening door de ondernemingen, waarvoor zij waren ingesteld, te bevorderen alsmede het gemeenschappelijk belang van die ondernemingen en van de daarbij betrokken personen te behartigen. ${ }^{21}$ Daartoe konden de product- en bedrijfschappen op eigen initiatief en ter uitvoering van deze taak bij verordening algemeen verbindende voorschriften vaststellen. Deze zogenoemde autonome verordeningen konden de product- of bedrijfslichamen inzetten om hun eigen doelen te realiseren, voor zover dit paste binnen de aan hen opgedragen taak. Van deze bevoegdheid werd bijvoorbeeld gebruik gemaakt om voorschriften te stellen ten aanzien van onderwerpen die door de rijksoverheid niet geregeld werden, maar wel in het belang van de betreffende sector werden geacht. Daarnaast kon van de product- en bedrijfschappen ook medewerking worden gevorderd door de overheid tot het stellen van algemeen verbindende voorschriften in zogenoemde medebewindsverordeningen. Om zijn regels afdwingbaar te maken beschikte het productschap over een tuchtrechtelijk instrumentarium en bestond de mogelijkheid om overtredingen aan te wijzen als strafbare feiten. ${ }^{22}$ Hiermee was verzekerd dat de naleving van deze verordeningen daadwerkelijk kon worden afgedwongen.

De rol van private partijen, vertegenwoordigd in de product- en bedrijfschappen, en die van de overheid verschilden al naar gelang er toepassing werd gegeven aan het autonome instrumentarium of het medebewindsinstrumentarium. Bij toepassing van de autonome verordeningsbevoegdheid was er enkel een rol voor de product- en bedrijfschappen. Zij konden dit instrument ter realisatie van hun eigen doelen inzetten zonder betrokkenheid van de rijksoverheid. ${ }^{23}$ In geval van de medebewindstaak lag dit anders. Medebewind werd gevorderd door de rijksoverheid en de schappen moesten hieraan, binnen de gestelde kaders, uitvoering geven. Hier was het aan de rijksoverheid om sturend op te treden. Met name de autonome verordeningen vormden daardoor voor de product- en bedrijfschappen een mogelijkheid om regulerend op te treden in de sector en maakten het mogelijk om te sturen op realisatie van bepaalde sectorale doelen. Voorbeelden betreffen diverse verordeningen van de Productschappen Vee en Vlees en Pluimvee en Eieren met voorschriften die veehouders in acht moesten nemen om de insleep van bepaalde dierziekten te voorkomen. Het betrof maatregelen waarvan de rijksoverheid het niet tot haar publieke taak rekende om deze te stellen. De productschappen zagen evenwel een meerwaarde in deze voorschriften om de positie van de Nederlandse veehouderijsector te versterken. Doordat de Wet BO voorzag in

20 Zie art. 66, eerste en tweede lid, Wet BO.

21 Zie art. 71 Wet BO.

22 Zie art. 104 Wet BO.

23 Voor de overheid bestond enkel een bevoegdheid deze verordeningen te vernietigen, met welke bevoegdheid zeer terughoudend werd omgegaan. 
een adequaat systeem van handhaving, kon ook de naleving van deze 'sectorregels' worden verzekerd.

Na veel discussie over het functioneren van de product- en bedrijfschappen en na een daartoe strekkende motie van de leden Aptroot, Van den Besselaar en Ulenbelt ${ }^{24}$ is in 2012 in het regeerakkoord 'Bruggen slaan' ${ }^{25}$ afgesproken om de product- en bedrijfschappen op te heffen en om de publieke taken van de bedrijfslichamen te beleggen bij de Minister van Economische Zaken. De kritiek op de product- en bedrijfschappen spitste zich toe op een tweetal aspecten. Ten eerste het bindende karakter van de verordeningen, en met name de heffingen, en ten tweede het gebrek aan democratische legitimatie bij de schappen. ${ }^{26}$ Zeker waar het de autonome bevoegdheden van de schappen betrof, knelden deze punten. Zo zou er sprake zijn van een beperking van het ondernemerschap en zou de doelmatigheid in een sector belemmerd worden doordat de schappen vergaande bevoegdheden hadden om ondernemers aan (financiële) voorschriften te binden, zonder dat die ondernemers voldoende inspraakmogelijkheden hadden om te kunnen verzekeren dat zij daadwerkelijk baat hadden bij die voorschriften. Op 1 januari 2015 zijn, met de inwerkingtreding van de Wet opheffing bedrijfslichamen, de product- en bedrijfschappen opgeheven. Daarmee is voor de betreffende sectoren een belangrijk instrument om sturend op te treden verloren gegaan.

\section{Wetsvoorstel ruimte voor duurzaamheidsinitiatieven}

Op 4 juli 2019 werd een voorstel van wet houdende regels ter bevordering van de totstandkoming en realisatie van maatschappelijke initiatieven gericht op duurzame ontwikkeling door na een daartoe strekkend verzoek deze initiatieven in regelgeving op te nemen (Wet ruimte voor duurzaamheidsinitiatieven) bij de Tweede Kamer ingediend. ${ }^{27}$ Aanleiding voor het wetsvoorstel ruimte voor duurzaamheidsinitiatieven is het spanningsveld tussen mededinging en duurzaamheid, in het bijzonder het kartelverbod. Het kartelverbod verbiedt overeenkomsten tussen ondernemingen, besluiten van ondernemersverenigingen en onderling afgestemde feitelijke gedragingen van ondernemingen die ertoe strekken of tot gevolg hebben dat de mededinging op de markt of een deel daarvan wordt verhinderd, beperkt of vervalst. Verschillende duurzaamheidsafspraken tussen partijen bleken niet tot stand te kunnen komen omdat deze in strijd waren met het kartelverbod. Bekendste voorbeelden zijn de Kip van Morgen ${ }^{28}$ en de afspraken rond de sluiting van de kolencentrales in het Energieakkoord. ${ }^{29}$ Naast deze problematiek lijken duurzaamheidsinitiatieven, blijkens de memorie van toelichting bij dit wetsvoorstel, tevens niet tot stand te komen vanwege free-

Kamerstukken II 2012/13, 33000 XV, nr. 61.

Zie www.rijksoverheid.nl/documenten/rapporten/2012/10/29/regeerakkoord.

Kamerstukken II 2013/14, 33910, nr. 3, p. 3-4.

Kamerstukken II 2018/19, 35247, nr. 2.

Kamerstukken II 2014/15, 30196, nr. 354.

Kamerstukken II 2013/14, 30196, nr. 2. 
riderproblematiek of coördinatieproblemen. De energie bij partijen om te komen tot duurzaamheidsafspraken kan hierdoor weglekken. ${ }^{30} \mathrm{Om}$ de totstandkoming van duurzaamheidsinitiatieven te ondersteunen en deze problematiek aan te pakken, is het wetsvoorstel tot stand gebracht.

Het wetsvoorstel biedt een grondslag om breedgedragen maatschappelijke duurzaamheidsinitiatieven te vertalen in regelgeving. Hiertoe kunnen partijen die een duurzaamheidsinitiatief hebben ontwikkeld een verzoek doen. Partijen omschrijven in dit verzoek welke duurzaamheidsdoelen zij willen bereiken en in hoeverre hiervoor draagvlak is onder partijen die de te stellen regels moeten naleven en onder andere betrokken partijen, en onderbouwen de gevolgen van de te stellen regels voor de duurzame ontwikkeling, de markteffecten en andere relevante gevolgen. Een dergelijk verzoek wordt vervolgens (politiek) eigenstandig en integraal gewogen. Beoordeeld wordt of het in het algemeen belang is dat naar aanleiding van een verzoek regels worden gesteld. In geval van een positieve uitkomst van deze weging wordt een algemene maatregel van bestuur, eventueel uitgewerkt in een ministeriële regeling, opgesteld. De ontwerpregelgeving wordt voor advies voorgelegd aan de Autoriteit Consument en Markt (ACM), die kijkt naar de markteffecten van de regelgeving, en een onafhankelijke derde partij wordt gevraagd te adviseren over de gevolgen van de regelgeving voor de duurzame ontwikkeling. Vervolgens wordt de ontwerpregelgeving voorgehangen bij de Eerste en Tweede Kamer. In geval van een positieve uitkomst van deze procedure wordt de regelgeving vastgesteld en gaat het duurzaamheidsinitiatief gelden voor eenieder. De overheid ziet toe op de naleving van de regels. Er is voorzien in bestuursrechtelijke handhaving.

Het wetsvoorstel, zoals ingediend, biedt een instrument voor private partijen om breedgedragen duurzaamheidsinitiatieven te realiseren. De procedure die het wetsvoorstel bevat om deze initiatieven te vertalen in regelgeving zou evenwel ook voor andere maatschappelijke initiatieven kunnen worden gebruikt. ${ }^{31}$ Met dit wetsvoorstel kunnen maatschappelijke partijen worden ondersteund bij de realisatie van hun (duurzaamheids)doelen. Deze partijen zijn degenen die de reikwijdte van het duurzaamheidsinitiatief en daarmee het verzoek bepalen. Tegelijkertijd is er een grote rol voor de overheid. Het is immers de overheid die op basis van een integrale afweging beoordeelt of het in het algemeen belang is om regels te stellen, en daarmee of het in het algemeen belang is dat een duurzaamheidsinitiatief voor eenieder gaat gelden. Doordat er regelgeving tot stand komt en voorzien is in bestuursrechtelijke handhaving, is geborgd dat de naleving van een duurzaamheidsinitiatief dat op grond van dit wetsvoorstel in regelgeving is opgenomen, kan worden afgedwongen.

30 Kamerstukken II 2018/19, 35247, nr. 3, p. 3-5.

31 Dit zou wel een wetswijziging vergen, omdat de reikwijdte van het wetsvoorstel thans beperkt is tot initiatieven die bijdragen aan een duurzame ontwikkeling. 
De Afdeling advisering van de Raad van State heeft een kritisch advies ${ }^{32}$ op het wetsvoorstel uitgebracht. Volgens de Afdeling wordt door de procedure die het wetsvoorstel bevat de vrijheid van de wetgever om op basis van een integrale afweging van alle relevante belangen te komen tot regelgeving te veel beperkt. Het risico zou bestaan dat (deel)belangen van de verzoekers zwaarder kunnen gaan wegen dan het algemeen belang. Verder zou het primaat van de wetgever worden aangetast door een te ruime en vergaande delegatiegrondslag. Ook maakt de Afdeling een opmerking over mogelijke juridisering van besluitvorming en gaat zij in op de effectiviteit van het voorstel en andere mogelijkheden om het beoogde doel te bereiken. In het nader rapport ${ }^{33}$ is uitgebreid ingegaan op deze aspecten van het advies.

Juist in deze bijdrage die gaat over instrumenten voor de realisatie en ondersteuning van maatschappelijke initiatieven valt over de door de Afdeling opgeworpen punten wel een en ander te zeggen. Ieder instrument kent zo zijn beperkingen. Zo wordt de mogelijkheid om te werken met publiek-private afspraken beperkt door de werking van het kartelverbod en problemen rond de afdwingbaarheid van gemaakte afspraken. Die problematiek geldt ook voor algemeenverbindendverklaring. Dit wetsvoorstel beoogt voor die mededingingsrechtelijke problematiek een oplossing te bieden. De afdwingbaarheid is bovendien verzekerd doordat de regelgeving die op grond van het wetsvoorstel tot stand komt bestuursrechtelijk wordt gehandhaafd. Een belangrijk bezwaar tegen de inmiddels afgeschafte product- en bedrijfschappen was het gebrek aan democratische legitimatie van de besluitvorming. In dit wetsvoorstel is in die legitimatie voorzien door, onder andere, een voorhangprocedure voor de op grond van het wetsvoorstel tot stand te brengen regelgeving. Parlementaire betrokkenheid is hiermee geborgd, waar dat ook bijvoorbeeld bij de algemeenverbindendverklaring en de publiek-private afspraken niet het geval is. Bezien in vergelijking met andere instrumenten, zoals hier besproken, valt er voor het wetsvoorstel dus zeker het nodige te zeggen.

Overigens is het wetsvoorstel naar aanleiding van het advies van de Afdeling wel degelijk aangepast, met name om te borgen dat daadwerkelijk op basis van een integrale afweging van het verzoek kan worden besloten om in het algemeen belang over te gaan tot het stellen van regels. Het is nu aan de Kamers om te bepalen of dit voorstel tot wet wordt verheven, waarna uit de praktijk zal moeten blijken hoe dit voorstel voor private partijen kan functioneren als instrument om duurzaamheidsinitiatieven met ondersteuning van de overheid te realiseren.

\section{Reguliere wetgeving}

Reguliere wetgeving wordt ingezet wanneer de overheid in het kader van haar publieke taak wenst op te treden ter realisatie van haar eigen beleidsdoelen. Regelgeving wordt ingezet om gedragingen of handelingen te normeren (aanwij- 
zing 2.1 van de Aanwijzingen voor de regelgeving) in het geval er sprake is van een maatschappelijk probleem dat hierdoor kan worden opgelost of verkleind. Vanzelfsprekend moet altijd worden beoordeeld of regelgeving het meest geschikte instrument is om het probleem op te lossen, of er geen minder bezwarende alternatieven beschikbaar zijn, en of de kosten en lasten van de regelgeving gerechtvaardigd worden door de ernst van het probleem (aanwijzing 2.2 van de Aanwijzingen voor de regelgeving). Dit is uiteindelijk aan de wetgever. Het is ook de wetgever die het toepassingsbereik van de te stellen regels bepaalt. Vanwege de aard van dit instrument is toezicht en handhaving aan de overheid. Daarmee is verzekerd dat naleving van de regels kan worden afgedwongen.

Tegelijkertijd is wetgeving geen solitair proces van de overheid. Ook maatschappelijke partijen hebben een rol bij de inzet van dit instrument, al is die rol veel beperkter dan bij enkele van de hiervoor genoemde instrumenten. Partijen kunnen invloed uitoefenen op het proces van totstandkoming van regelgeving. Dat kan bijvoorbeeld door met de overheid in gesprek te gaan en de overheid te verzoeken bepaalde regels te stellen. Ook komt het voor dat maatschappelijke partijen betrokken zijn bij het opstellen van regelgeving, bijvoorbeeld doordat hen al in een vroeg stadium om inbreng wordt gevraagd, of doordat partijen actief meeschrijven aan regelgeving. ${ }^{34}$ In het verdere proces kunnen partijen ook inbreng leveren, bijvoorbeeld via de internetconsultatie of tijdens het parlementaire proces. Daarnaast worden ook steeds vaker bestuursakkoorden gesloten, ${ }^{35}$ als gevolg waarvan wetgeving (al dan niet ter ondersteuning van de gemaakte afspraken) tot stand komt. Maatschappelijke partijen hebben evenwel geen formele rol in het proces van totstandkoming of uitvoering van de regelgeving. Een rol waar deze partijen vaak wel naar op zoek zijn, zeker wanneer een instrument wordt ingezet om initiatieven of doelen van die partijen te realiseren.

Vanuit de overheid wordt wel steeds gewerkt aan moderne en innovatievriendelijke wetgeving, waarmee ruimte wordt geboden voor maatschappelijke en technologische ontwikkelingen. ${ }^{36}$ Voorbeelden hiervan zijn het right to challenge, experimenteerbepalingen en vrijstellingen. Met de inzet van deze instrumenten kan aan maatschappelijke partijen ruimte worden geboden om bepaalde initiatieven te ontplooien, echter steeds binnen de door de overheid daartoe te stellen kaders.

\section{Wat brengt dit ons?}

De logische conclusie die ten aanzien van de hiervoor beschreven instrumenten kan worden getrokken, is dat per geval moet worden bezien welk instrument in de betreffende situatie het beste kan worden ingezet. Toch kan hierover wel iets

34 Zie hierover ook Uitbesteding van wetgeving (preadviezen voor de Nederlandse Vereniging voor Wetgeving), Oisterwijk: Wolf Legal Publishers 2017.

35 R.A. Koole, 'Is een “akkoorden-democratie” wel een democratie?', RegelMaat 2019, afl. 2, p. 96.

36 Kamerstukken II 2017/18, 32637, nr. 314, p. 1. 
meer worden gezegd. Burgers, bedrijven en organisaties in Nederland willen bijdragen aan maatschappelijke opgaven en de overheid wil hen daarin ondersteunen. Die ondersteuning kan betrekking hebben op realisatie van brede deelname aan initiatieven, maar ook op de mogelijkheid om uitvoering of naleving van initiatieven te verzekeren. Tegelijkertijd zoeken partijen ook naar een manier om hun rol in deze processen (formeel) te borgen, zodat invloed verzekerd is. In deze bijdrage zijn diverse instrumenten besproken die maatschappelijke partijen en de overheid (samen) in kunnen zetten om maatschappelijke initiatieven te realiseren. In figuur 1 zijn deze instrumenten en de belangrijkste kenmerken daarvan weergegeven.

Zelfregulering kan door maatschappelijke partijen worden ingezet. De beperkingen van dit instrument zijn echter die situaties waarin onvoldoende deelname aan zelfregulering wordt gerealiseerd of de naleving onvoldoende kan worden afgedwongen. Ondersteuning van zelfregulering door de overheid is mogelijk, maar steeds zal bezien moeten worden of ondersteuning noodzakelijk is en wat daarvoor de juiste vorm is. De andere kant van deze medaille is reguliere wetgeving. Met de toepassing van dit instrument is verzekerd dat eenieder aan de te stellen voorschriften gebonden is en is ook naleving van de voorschriften af te dwingen. Het is echter een instrument dat door de overheid wordt ingezet. De rol voor en invloed van maatschappelijke partijen zijn beperkt.

Bij het maken van publiek-private afspraken is er een gelijkwaardige rol en positie voor partijen. Dit maakt dat met dit instrument zowel door private partijen als door de overheid sturing mogelijk is. Ook hier geldt dat brede deelname niet kan worden afgedwongen en dat het verzekeren van de naleving van de gemaakte afspraken niet per definitie eenvoudig is. Ook brengt het kartelverbod een belangrijke beperking mee voor de mogelijk te maken afspraken.

Bij algemeenverbindendverklaring ligt het initiatief bij private partijen. De rol van de overheid is beperkt tot het creëren van een grondslag voor algemeenverbindendverklaring en ondersteuning in de vorm van het nemen van een besluit tot algemeenverbindendverklaring. Dit maakt de ruimte voor de overheid om sturend op te treden heel beperkt. Ook is het lastig te bepalen wanneer dit instrument meerwaarde biedt: het moet gaan om een onderwerp waarvan de regeling aan private partijen behoort te worden gelaten, maar het wel wenselijk is om die regeling voor de hele sector te laten gelden, en het aan de overheid moet zijn om dit te faciliteren. Complicerende factor van dit instrument is dat er sprake blijft van private afspraken die partijen zelf uit moeten voeren, en waarvan partijen zelf de naleving moeten afdwingen met behulp van het privaatrechtelijk instrumentarium. Bovendien geldt ook hier de beperking die het kartelverbod meebrengt.

Het instrument van de (autonome) productschapsverordeningen bood het bedrijfsleven de mogelijkheid om algemeen verbindende voorschriften vast te stellen ter verwezenlijking van hun eigen doelen. Bovendien kon de naleving van 
Figuur 1 Overzicht van instrumenten om maatschappelijke initiatieven te realiseren

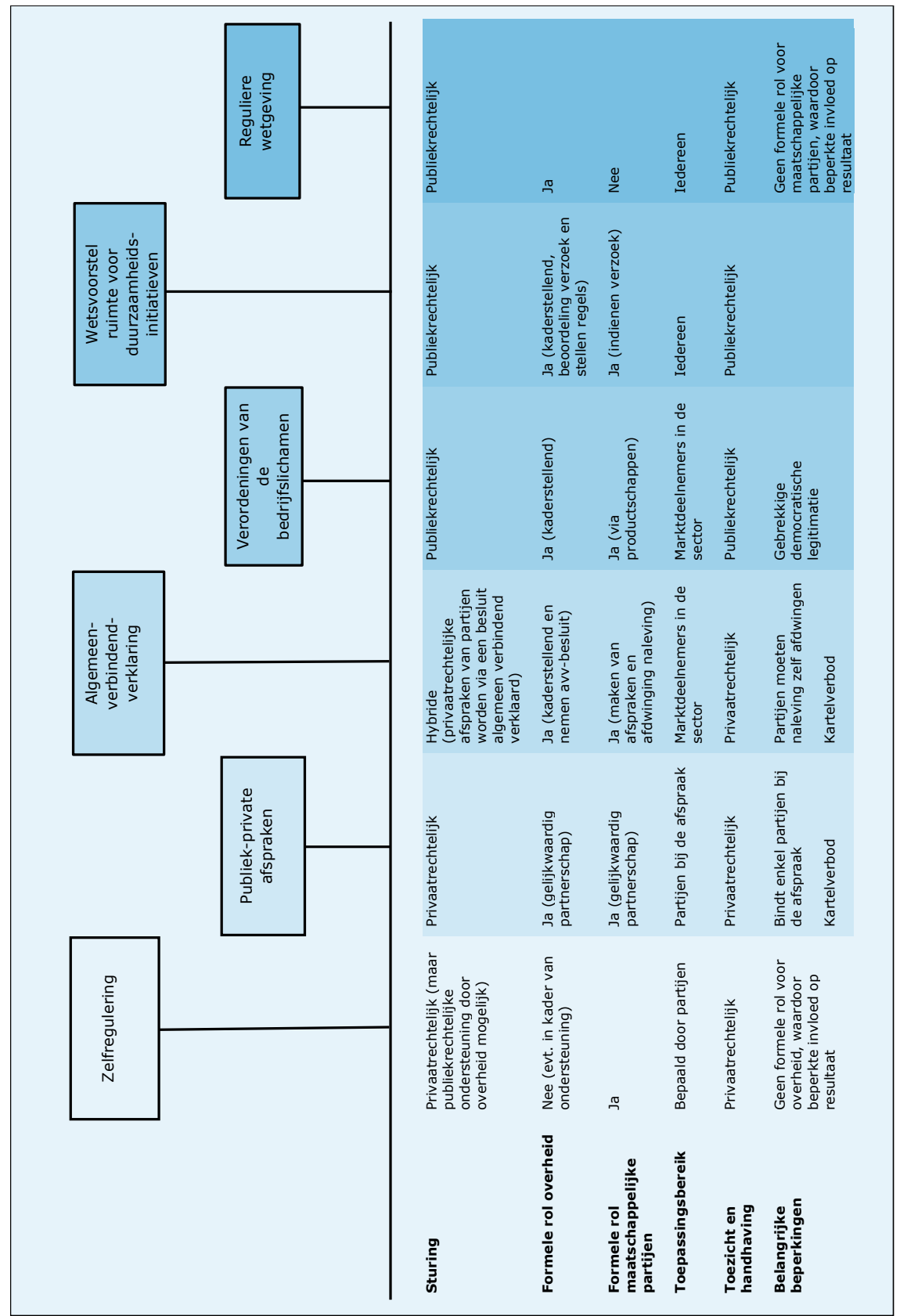


deze voorschriften effectief worden afgedwongen. De bezwaren tegen dit systeem, waaronder de gebrekkige democratische legitimatie, wogen echter zwaarder en hebben geresulteerd in afschaffing van de bedrijfslichamen.

Een bruikbaar alternatief biedt wellicht het wetsvoorstel ruimte voor duurzaamheidsinitiatieven. Dit betreft een instrument waarbij private partijen een formele rol hebben. Het wetsvoorstel biedt immers enkel een grondslag om over te gaan tot het stellen van regels voor zover daaraan een verzoek van private partijen ten grondslag ligt om een duurzaamheidsinitiatief te vertalen in regelgeving. Het is echter de overheid die op basis van een integrale afweging beslist of het in het algemeen belang is om deze regels te stellen. De mogelijkheid om de naleving van de regels af te dwingen is hierdoor eveneens verzekerd. Of dit wetsvoorstel uiteindelijk zal worden ingezet, is vooralsnog aan het parlement. 